\title{
The Postnatal Histogenesis of the Thyroid Gland of the Golden Hamster (Cricetus Auratus)
}

\author{
By \\ Tamiko Sato \\ The 2nd Department of Anatomy, Nagoya City University Medical School \\ (Directors: Profs. Drs. S. Sug i y ma ${ }^{1)}$ and $\mathrm{H}$. U e mat s u) \\ With 14 Figures
}

\section{Introduction}

Numerous reports have been published so far on histological studies of the thyroid glands of mammals. The thyroid glands of rodents, as common laboratory animals, have also been often subjected to these studies. Notwithstanding this, there are only a few postnatal histogenetic studies of this organ of rodents ( $\mathrm{S} u \mathrm{~g}$ i y a ma '39, rats; Sug i y a ma, '50, S u g i y a $\mathrm{m}$ a and $\mathrm{Y}$ a g i z a w a '50, rabbits ; $\mathrm{Sug}$ i y a m a, '54, Sug i y a $\mathrm{m}$ a and $\mathrm{Sat} 0$, '54, guinea pigs). The golden hamster is a species of rodent, but its thyroid gland has not been studied from this aspect. Recently, K r o o n ('58) observed the formation of intrafollicular follicles in the thyroid gland of golden hamsters as a result of the administration of thiouracil derivatives. According to him, the formation of intrafollicular follicles is a reaction characteristic of the thyroid gland of golden hamsters, a reaction which has never been found in other animals. This is true to some extent of the normal histology of the thyroid gland of golden hamsters. In pursuance to previous studies of the thyroid gland of guinea pigs, the author undertook investigations to elucidate the thyroid gland of golden hamsters as regards histogenesis, of quantitative histometrical measurements of the follicles and follicle cells and radioautography with radioiodine ${ }^{131}$, in the hopes that this study may serve as a basis for other studies of the thyroid gland of golden hamsters.

\section{Material and Methods}

A total of 210 golden hamsters, male and female, were used in

1) Shooichi Sugiyama: present adress: Department of Anatomy, Nagoya University School of Medicine, Tsurumai-Cho, Nagoya. 

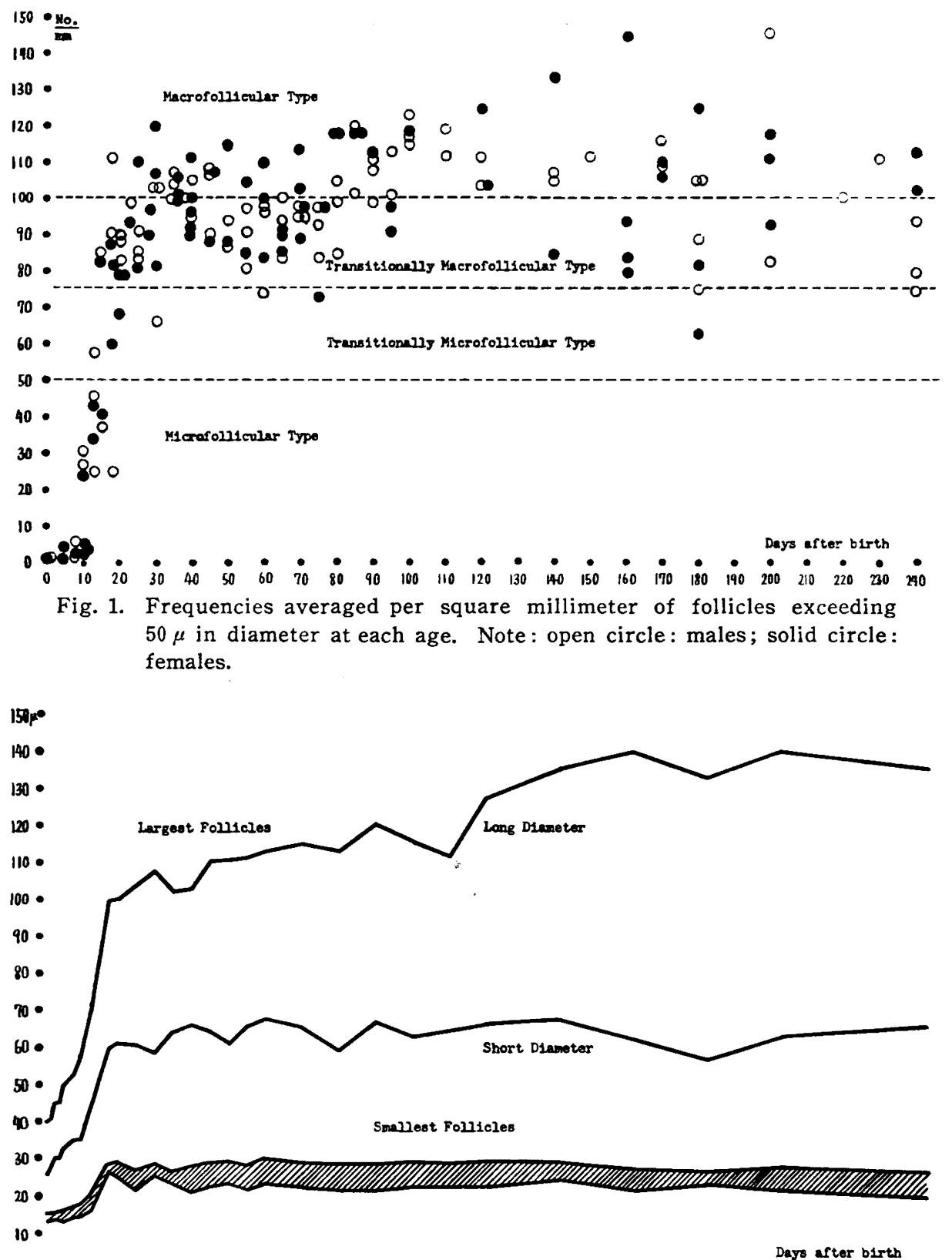

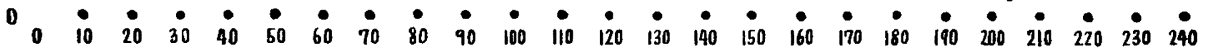

Fig. 2. Development of dimensions averaged of 20 largest and smallest follicles regarded as representative of each age. Note: striped band: ranges of diameters of smallest follicles. 
this study. They ranged in age from immediately after birth to 240 days (figs. 1, 2 and 3). The animals were fed fresh greens, dried

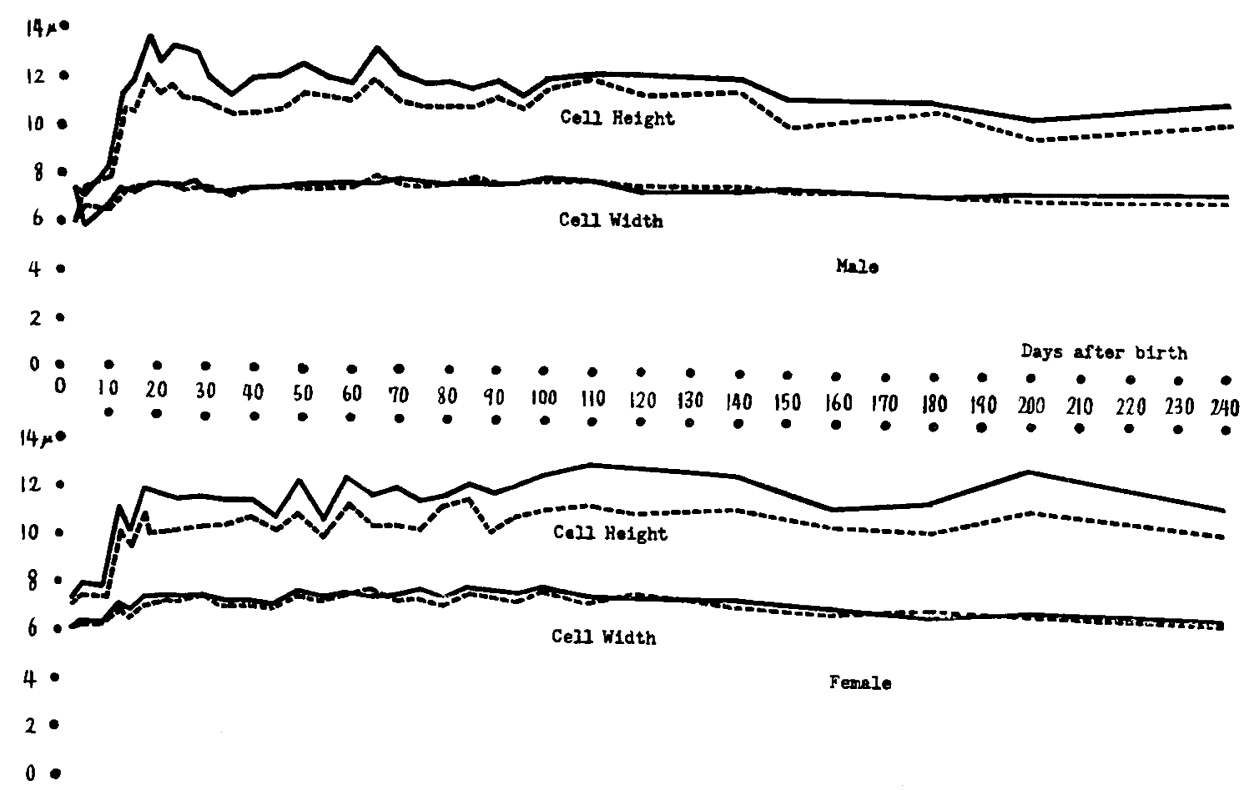

Fig. 3. Development of heights and widths averaged per age of 100 follicle cells regarded as representative, in follicles situated in the peripheral and central zones of the thyroid gland. Note: continuous lines: heights and widths of follicle cells of peripheral follicles; broken lines: heights and widths of follicle cells of central follicles.

small sardines and wheat grains ad libitum. Most of them were sacrificed during the temperate seasons. The fixatives used were Zenker's, Helly's and Kolster's fluids. The materials were embedded in paraffin, cut transversely at $6 \mu$ and mounted serially. Most of the sections were stained by $\mathrm{H}$ an se n's hematoxylin and eosin, and by $\mathrm{Heidenhain's} \mathrm{iron} \mathrm{hematoxylin,} \mathrm{and} \mathrm{some} \mathrm{by}$ We igert's resorcin fuchsin for demonstrating elastic fibers, with Bielschowsky's silver impregnation method for argyrophilic fibers and with azan stain for connective tissue fibers. Some of the sections fixed in Helly's fluid were stained by periodic acid$\mathrm{S} c \mathrm{~h}$ iff's stain for detecting glycogen and other substances in the thyroid parenchyma, in combination with saliva digestion.

The histometrical measurements of the follicles and follicle cells were made on the middle one-third of the lateral lobe. Follicles over $50 \mu$ in diameter were regarded as large follicles and their frequency 
per square millimeter of occurrence was calculated. The number contained within 10 sections consisting of every 5th section was examined by the ratio, frequency averaged per section/averaged section area (fig. 1). The averaged diameters of the 20 largest and 20 smallest follicles, which were regarded as representative, were estimated per animal by measuring their long and short diameters, and again averaged per stage (fig. 2). These measurements were utilized for elucidating the trend of follicles in each period of life. The heights and widths of 100 follicle cells found respectively in the peripheral and central zones of the gland were estimated by the usual methods, and averaged per animal and subsequently per stage (fig. 3). A single tracer dose of $45 \mu \mathrm{c}$ of radioiodine ${ }^{131}$ was subcutaneously injected into three animals 31,59 and 122 days old, and after 24 hours the animals were sacrificed. The thyroid glands were examined by the stripping film technique to determine the presence of accumulated radioiodine and its distribution.

To examine various forms of follicles, wax plate reconstruction models were made by the use of serial transverse sections impregnated by silver (fig. 12).

The life span of golden hamsters was divided into the following 4 periods: (1) suckling period-from birth to the 20 th day ; (2) infancy-from approximately the 20 th to the 40 th day; (3) puberty (sexual maturity)-from approximately the 50th to the 80 th day; and (4) adult period-from approximately the 80th to the 240 th day. This division was based upon the observations of the present author and Bruce et al. ('34). It was fourd that males and females attain sexual maturity at 50 to 60 days after birth, and, in most cases, the first litters are not born until the females are approaching the age of 80 days.

\section{Observations}

FOLLICLES-connected with each other without open communication of their cavities, and formed follicular networks and chains (figs. 6 and 12). Large follicles were generally found in the peripheral zone of the gland and small follicles in the central zone, as were found in rats (J a cks n, '16; Sugi yama, '39) and mice (O hida, '54). The large follicles were more irregular in shape (figs. 7, 8 and 14), but the small follicles were round to oval, and relatively regular in shape. 
Follicles over $50 \mu$ in diameter were regarded as large follicles, and, as shown in figure 1, their frequency per square millimeter was plotted according to the progress of time after birth. By measurements of the frequency the thyroid gland was classified into the following categories: microfollicular type (below 50 per square millimeter), macrofollicular type (over 100) and intermediate type subdivisible into transitionally microfollicular (from 50 to below 75) and transitionally macrofollicular (from 75 to below 100) types. The microfollicular type appeared to be characterized in sections by an absolute predominance of follicles between 15 and $25 \mu$, and admixed with very small follicles between 12 and $15 \mu$ (figs. 4 and 5). The macrofollicular type appeared to be marked in sections by an absolute prevalence of large follicles between 50 and $75 \mu$ (figs. 7 and 8). This type sometimes contained a number of large follicles over $100 \mu$. The largest follicles found in this type were averagely $85 \mu$, the maximum being $167 \mu$. No sex difference was found in the trend of follicular type found in each period of life (fig. 1).

In the suckling period, the thyroid gland is of the microfollicular type (fig. 1). Most of the follicles were regularly round to oval (figs. 4 and 5). The averaged diameter of the largest follicles was 33 to $68 \mu$, and that of the smallest follicles 14 to $22 \mu$ (fig. 2). From the end of this period, follicles grew rapidly in size. There were other arrangements of epithelial cells, such as cell cords and cell conglomerates, in which a number of primitive follicles were found (fig. 4). Further, primitive follicles were also found as buds in the follicles (fig. 4). The primitive follicles showed already central intercellular splits containing little or no secretory product, and persisted until 20 days. Epithelial cells of the primitive follicles were wedge-shaped but almost the same in histologic character as the follicle cells.

In infancy, the thyroid gland was undergoing change from the microfollicular type to the macrofollicular type with a rapid increase in the frequency per square millimeter of follicles over $50 \mu$ (fig. 1). At the same time, most of the follicles, especially those in the peripheral zone of the gland, became gradually irregular in shape. The averaged diameter of the largest and smallest follicles were respectively 80 to $83 \mu$ and 24 to $28 \mu$.

With the advent of puberty, the thyroid gland changed from the macrofollicular type to the transitionally macrofollicular type with a slight decrease in the frequency per square millimeter of 
follicles over $50 \mu$ (figs. 1 and 6), and it remained in the same follicular type until the end of puberty. Irregular change in shape of the follicles proceeded further during this period, and especially in the peripheral zone. Single and branched tubular shapes were very often found (fig. 6). This fact may be indicated in figure 2 by marked numerical difference between the large and short diameters of the largest follicles. The averaged diameter of the largest and smallest follicles were respectively 84 to $90 \mu$ and 24 to $27 \mu$.

After puberty the thyroid gland became again macrofollicular, with increased irregularization of follicles. Nipple-like septums and bolster-like elevations of the follicle walls were sometimes found in irregular-shaped large follicles (figs. 7 and 8). The septums and elevations contained only a core of connective tissue and a few capillaries, but no primitive follicles and small follicles-no indication of production of new follicles within them. The averaged diameters of the largest and smallest follicles were respectively 88 to $112 \mu$ and 24 to $27 \mu$.

FOLLICLE CELLS-immediately after birth, were cubical and were slightly higher in. peripheral large follicles than in central small follicles, with height 7 to $7.4 \mu$ and width $6 \mu$. This state persisted until the end of the suckling period (figs. 3 to 5). From the beginning of infancy the follicle cells increased conspicuously in height and the follicle cells of peripheral large follicles became highly columnar. At the 20th day, the height of the follicle cells showed about a two-fold increase over the suckling period. It was 12 to $13 \mu$ in males and 11 to $12 \mu$ in females. The width of the follicle cells, however, showed only a slight increase of $1 \mu$.

During puberty the follicle cells remained almost in the same state in height as in the previous period (fig. 6). Even after puberty, the follicle cells showed no marked difference in height from those during puberty (figs. 7 and 8). There was a sex difference between the increases of follicle cell height in the adult period, and the height was slightly greater in females (fig. 3).

No intercellular canalicules were found in the follicle walls.

The nuclei of the follicle cells were somewhat irregular in shape shortly after birth (one to 5 days after birth), but soon later became swollen round to oval, their diameters being 6 to $7 \mu$. They were generally located in the central portion of the cell, but occasionally near the apical portion, especially in the follicle cells of irregularshaped large follicles. The chromatin reticulum was moderately 
dense and the nucleoli were indistinct.

The cytoplasm was generally finely granular. The granularity was not marked in the follicle cells in the suckling period, but increased in degree towards puberty. The cytoplasm was rarely loaded with secretory droplets, but somewhat frequently during puberty. They were round, of various sizes and of different shades of black by iron hematoxylin stain, and were present chiefly in the apical portion of the cell. On the other hand, the cytoplasm contained sometimes a homogeneous substance in the basal portion of the cell. This substance was almost identical in staining with the follicle colloid and gray by iron hematoxylin stain. Increased accumulation of this substance displaced the nuclei towards the apical portion and compressed them (fig. 11). The nuclei appeared like those of fat cells and sometimes were pyknotic. The substance appeared relatively often in puberty.

Colloid cells were found in relatively small numbers. Their nuclei appeared like those of ordinary follicle cells, but some were more chromatic and pyknotic. The cytoplasm was more eosinophilic and periodic acid-Schiff positive. The positivity remained uninfluenced by saliva digestion.

Mitotic figures of the follicle cells were always tound in abundance from birth to the 8th day and became infrequent after the 30th day. But even in adults, they were found though very rarely. Mitotic figures occurred not always frequently in irregular-shaped follicles. They were not found frequently in nipple-like septums or in bolster-like elevations of the follicle walls.

PARAFOLLICULAR CELLS-were of different sizes but generally larger than ordinary follicle cells (figs. 9 and 10). They were on the average $18 \mu$ (15 to $21 \mu)$ in the long diameter and $12 \mu$ (11 to $13 \mu)$ in the short. Their nuclei were round to oval, slightly larger than those of the follicle cells, with diameters 6 to $8 \mu$, and often were eccentrically located. They showed generally a finer chromatin reticulum, with or without a characteristic distribution of several chromatin particles-a wheel-like arrangement.

The cytoplasm was chromophobic to an extent which made them readily distinguishable from adjacent follicle cells, especially in Kolster-fixed preparations and showed some granularity. By periodic acid-S c h iff's stain, the cytoplasm was feebly red purple and this positivity remained unchanged by saliva digestion.

The majority of the parafollicular cells were located closely upon 
the follicle walls singly or in groups (fig. 9). When in groups, they gathered together as buds and sometimes formed cell plates immediately connected to the follicle wall. Some of the parafollicular cells bordered directly the follicle cavity. This gave an impression that the parafollicular cells may differentiate from the follicle cells and migrate from here towads the parafollicular position. The parafollicular cells sometimes forced adjacent follicle cells to become deformed or be stretched out (fig. 9).

The parafollicular cells appeared for the first time on the 3rd day after birth, and increased with age, being most numerous during puberty, and later decreased. Mitotic figures of the parafollicular cells were rarely found. It is of special interest that the parafollicular cells were found distributed evenly in small numbers in follicles of the central zone of the gland in ordinary cases, and more numerously in some cases where the ultimobranchial cysts were found in the thyroid lobe. In these cases, the parafollicular cells were seen abundantly in follicles near the ultimobranchial cysts, and further were entirely identical in histological appearance with some of the clear cells forming the walls of the cysts (fig. 10).

COLLOID-of the thyroid glands of golden hamsters contrasted with that of other mammals. The colloid was rather dilute, small in amount and contained little radioiodine ${ }^{131}$ (figs. 13 and 14) in most of the follicles. Accumulation of radioiodine had some relation with that of colloid in the follicles and considerable accumulation of it was seen only in a number of peripheral follicles, which contained a considerable amount of colloid.

The colloid was homogeneous, eosinophilic and rarely basophilic, in ordinary preparations fixed in Z e n ker's or Helly's fluid and stained with Hansen's hematoxylin and eosin. With azan stain the colloid was stained blue in a dilute state, but reddish orange in a concentrated state. In preparations fixed in $\mathrm{Kols}$ te r's fluid and stained with $\mathrm{He}$ ide $\mathrm{nh}$ ain's iron Hematoxylin, the colloid was stained blue black to gray. The colloid was red purple with periodic acid-S $\mathrm{c}$ i f f's stain and remained unchanged by saliva digestion.

On the first day after birth, the colloid stained darkly in many follicles of the gland (fig. 4). Soon later, the colloid increased in amount, and for a while (5 to 10 days after birth) it stained darkly only in the peripheral large follicles and feebly in the central smaller follicles (fig. 5). From the end of the suckling period, the colloid increased further in amount but its stainability became 
weaker. In peripheral large follicles, the colloid stained feebly and was vacuolated, while in central smaller follicles it was much more vacuolated. As a result of this, it was found that the colloid is often shrunken from the periphery, forming a small central mass with a jagged border. This state persisted until puberty. After puberty, typical colloid which stained darkly and slightly vacuolated, began to appear again only in a number of peripheral large follicles. The colloid found in most of the follicles remained stained feebly and much vacuolated (figs. 7 and 8).

CONNECTIVE TISSUE-interlobular and perifollicular, contained a considerable amount of connective tissue fibers and argyrophilic fibers, with no elastic fibers. Shortly after birth, the interlobular connective tissue was relatively distinct due to the loose arrangement (fig. 5). The formation of lobules was more distinct in the peripheral zone of the gland. At the 10th day, the interlobular connective tissue became indistinct due to denser arrangement by rapid growth of follicles, but in later life persisted only in the peripheral zone of the gland. The perifollicular connective tissue was derived from the interlobular and capsular connective tissues, and its argyrophilic fibers formed a thin layer directly around the follicles (fig. 6), and at the same time enclosed circularly the perifollicular capillaries.

From the 28th day on, fat cells began to appear within the perifollicular and interlobular connective tissue. They were found in abundance in the transition between the lateral lobe and isthmus, and formed fatty tissue, by which finally both parts became completely separated from the 80th day on.

The capsular connective tissue of the thyroid, at the same time, represented the perimysium of the infrahyal muscles at its lateral part and the adventitia of the trachea and larynx at its medial part. It contained considerable amounts of connective tissue fibers and argyrophilic fibers, but only a little elastic fiber.

BLOOD VESSELS-The arteries were already recognizable immediately after birth within the capsule and interlobular connective tissue, and grew in size on the 5th day. With the first formation of the lamina elastica on the 10th day, they developed further with age. The veins also were found immediately after birth, accompanied by the arteries and grew in size later, but most of them remained composed of the intima and adventitia, without muscle fibers.

The capillaries increased in number with repeated division of their endothelial cells in early life and formed more abundant plex- 
uses around growing follicles. Immediately after birth, the capillaries were engorged. But the engorgement became mild during the suckling period. Soon later the capillary engorgement increased again towards the puberal period and remained in the same condition until the beginning of the adult period. From the 180th day, the capillary engorgement became mild, but varied in degree from individual to individual. The capillaries of ten bulged into the follicle walls, indenting the basal surface of the follicles. However, they were not found completely within the follicle epithelium. Silver-impregnation demonstrated clearly this (fig. 6). This finding resembles that of Bucher ('40).

\section{Discussion}

FOLLICLES-of golden hamsters are larger in the peripheral zone of the gland than in the central zone. This agrees with the data of other rodents (J a c k s o n, ' 16 , rats; S u g i y a ma, '39, rats ; $\mathrm{O} \mathrm{h}$ i d a, '54, mice), but differs from that of guinea pigs ( $\mathrm{S}$ u g i y a $\mathrm{m}$ a and $\mathrm{S}$ a t 0 , '54).

Recently, Hammer and Loeschcke ('34) indicated by wax plate reconstruction models of the thyroid parenchyma of human newborn infants, that the acinus units (Drüsenfelder) are present in the lobules. According to them, the acinus units may be comparable to a certain extent with those of the exocrine gland and represent a branching tubular system consisting of collecting ducts of various orders and terminal portions. Kule $\mathrm{nkampff}$ ('50) confirmed also the presence of the acinus in the thyroid gland of the newborn by the same method. On the other hand, some insisted the existence of the "Zentralkanälchen"-irregular-shaped tubular follicle-in the thyroid lobules of the human being, which serves to produce new follicles (Klose, '16; A sch off, '25). It was found in golden hamsters by preparing wax plate reconstruction models that the exocrine glandular pattern and "Zentralkanälchen" do not exist in the gland, although irregular-shaped follicles often occur (figs. 4 to 8). F l o r e $n$ t in ('30) found two different zones, zone folliculeuse in the periphery of the gland and zone tubuleuse in the center in hedgehogs. The thyroid glands of golden hamsters showed no such two different zomes.

Follicles, rather, connect with each other directly by their epithelial walls, without open communication of their cavities, and form 
anastomosing follicular networks (fig. 6). Wax plate reconstruction models of follicles demonstrate this (fig. 12) and suggest that the thyroid gland of golden hamsters is included in the association type of $\mathrm{He}$ ide $\mathrm{nh}$ ain ('21). This is also in agreement with the data of rodents ( $\mathrm{Yag} \mathrm{iz} \mathrm{a} \mathrm{wa,} \mathrm{'56).} \mathrm{The} \mathrm{association} \mathrm{of} \mathrm{follicles} \mathrm{is} \mathrm{marked}$ in earlier stages of life, but the dissociation of follicles proceeds with age.

The growth of the follicles has been also observed in relation to the age of animals. Hell wig ('33) described that the growth of the follicle is found in those 13 to 16 years of age in man but retarded by about three years in women. Montez de O c a ('30) found in the Japanese of the Tokyo District that the glands are parenchymatous-microfollicular in type until puberty, macrofollicular from puberty to 30 years, and macrofollicular-microfollicular from 30 to 60 years of age. Stef $\mathrm{ko}$ ('34) described in man that the follicles begin to grow from 6 to 8 months, grow slowly at 5 to 7 years and abruptly at 8 to 11 years, and reach a maximum at 15 to 16 years of age. Sugi y a ma ('50) described in rabbits that the thyroid gland is parenchymatous-microfollicular immediately after birth, parenchymatous-macrofollicular in the suckling period, parenchymatous-microfollicular in the infant period, microfollicular-macrofollicular at puberty and macrofollicular-microfollicular after puberty. $\mathrm{S} u \mathrm{~g}$ i y a $\mathrm{m}$ a and $\mathrm{S}$ a to ('54) observed in guinea pigs that the thyroid gland is microfollicular immediately after birth, macrofollicular in the suckling period, transitionally microfollicular during early infancy, microfollicular during early puberty and macrofollicular after puberty. Spagnoli and Charipper ('55) described in hamsters that the follicles are uniformly small during the first two months after birth and thereafter grow gradually in size.

The present observations (fig. 1) showed that the glands are microfollicular immediately after birth, still of almost the same type during the suckling period (figs. 4 and 5), transitionally macrofollicular to macrofollicular during the infant period, transitionally macrofollicular with a slight decrease of follicles over $50 \mu$ during puberty (fig. 6) and macrofollicular after puberty (figs. 7 and 8). No sex difference is found in the trend of follicular type (fig. 1). With change of the follicular type, the averaged diameters of the largest follicles.increase strikingly, but the diameter of the smallest follicles remains almost without change (fig. 2). It is of much interest that the thyroid glands of rodents including golden hamsters ( $\mathrm{S} \mathrm{u} \mathrm{g} \mathrm{i} \mathrm{y} \mathrm{a} \mathrm{m} \mathrm{a}$ 
and $\mathrm{Y}$ a g i z a w a, '50, rabbits; $\mathrm{S} \mathrm{u}$ g i y a $\mathrm{m}$ a and $\mathrm{S}$ a t 0 , '54, guinea pigs) reveal a trend to more or less marked reduction in size of follicles during puberty. This is in contrast with the data observed in the human being.

Sobotta ('15), We gelin('26), Caylor and Schlot thauer ('27), S pöttel ('29), Geuer ('31), Watzka ('34) and Cowdry ('34) pointed out various factors that influence the follicle shape. Sobotta described in the human thyroid gland that the shape of follicles depends upon the increase and decrease of the follicle content. Cow dry suggested that follicles become very irregular in shape with formation of nipples in their walls in hyperactivity of the gland. Wegeli $n$ interpreted the irregular shapes of follicles to be caused by fusion and division of follicles. On the other hand, it was found that the shape of the follicles is related to the age of animals. Wat $\mathrm{zk}$ a found some difference in shape of follicles in the thyroid glands of pigs before and after birth. According to him, on the first day after birth follicles indicate narrow and small cavities due to depletion of colloid. C a y lor and S $\mathrm{chl}$ ot tha u e r reported in pigs that the follicles are irregular in shape before puberty and become round to oval after this time. Contrary to them, $\mathrm{Ge}$ e e $\mathrm{r}$ described in horses that the follicles are distended in young animals and become rather irregular in shape in old animals.

In golden hamsters shortly after birth, the follicles are rather regular-shaped, round to oval (figs. 4 and 5). A dominant occurrence of irregular-shaped follicles begins from the infant period on, being exaggerated in degree during puberty and persists as a normal state characteristic for the thyroid gland of golden hamsters even in later life (figs. 6 to 8 ).

Concerning the mechanism of the formation of new follicles from parent follicles, there have been a considerable number of different observation-(1) budding process (I senschmid, '10, man ; W e g e li n, '26, man; Wilson, '27, man; Spöt te l, '29, sheep ; $\mathrm{S} \mathrm{u}$ g i y a m a, '39, rats ; $\mathrm{S} u \mathrm{~g}$ i y a m a et al., '58, human infants): (2) fusion of the follicles to produce a new follicle (We ge li n, '26, man; Z e che l, '31 a, dogs): (3) division of the follicles by nipplelike elevation of the follicle wall (I se n s chmid, '10, man; W e g el i n, '26, man; S p öt t e l, '29, sheep).

Some of the investigators described the cyclic change of alternate breakdown and reformation of follicles in mammals. A n dersson (1894) found new follicles arising from collapsed epithelium of 
emptied follicles in mammals. Z echel ('31 a, b; '33) found this process in dogs and man, and $\mathrm{Hermann}$ ('33) in domestic animals. On the other hand, Goor maghtigh et al. ('34) suggested some evidence of alternating periods of different follicular patterns due to release and storage of colloid, and demonstrated that the depletion of colloid in large follicles results in the formation of new small follicles. These may be considered to be included in the (4)th way. The (5)th way is that follicles are formed from the interfollicular epithelium (Florentin and Grujic, '29 a, b, guinea pigs; Kolmer, '31, rabbits; Ge uer, '31, horses ; Z al esky, '35, ground-squirrels; S u g i y a ma, '54, guinea pigs).

In golden hamsters, new formation of follicles-formation of primitive follicles-appears to be derived by budding process in the follicle walls shortly after birth, and further from cell cords and cell conglomerates (figs. 4 and 5). Within the primitive follicles central intercellular splits occur and are transformed into a follicle cavity. Fusion and division of the follicles appear to play only a minor role in the new formation, because of no accurate evidence of degeneration in the contacting areas of two adjacent follicles, and fusion of two opposite nipple-like elevations of the follicle walls (figs. 7 and 8).

FOLLICLE CELLS-have been reported to be generally high in young animals and low in old animals ( $\mathrm{Jackson}$, '16, rats; Spöttel, '29, sheep; Berberich and Fischer-Wasels, '32, man). Caylor and Schlotthauer ('27) described in pigs that the follicle cells are columnar before puberty and become low cubical to flat after puberty. Wat z ka (34) also found hypertrophy of the follicle cells in the glands of rabbits and pigs shortly before and after birth.

In golden hamsters shortly after birth, most of the follicle cells are rather small, cubical and not hypertrophied and remain in almost the same condition during the suckling period (figs. 3 to 5). At the beginning of infancy, they become rapidly columnar with a two-fold increase in height, and persist in the same condition up to a later period (figs. 6 to 8). Some sex difference is found in the increase of follicle cell height in the adult period, but its significance remains unsettled (fig. 3).

On the other hand, the follicle cells have been reported to be also different in height in the central and peripheral zones of the gland. In mature animals, the follicle cells are higher in the central 
zone than in the peripheral zone ( $\mathrm{Jackson}$, '16, rats; $\mathrm{Sug}$ i y a ma, '39, rats; Sug i y a ma, '54, guinea pigs; O hid a, '54, mice) while this condition is reversed in young animals. In golden hamsters, however, the follicle cells remains always higher in the peripheral large follicles, and especially highly columnar in later stages (figs. 3 and 8 ).

The nuclei of the follicle cells have been described as being situated centrally or towards the base of the cell (Sobotta, '15, man; W e geli n, '26, man; Su g i y a ma, '39, rats; Sug i y a ma, ' 54 , guinea pigs; $\mathrm{O} \mathrm{h}$ id a, ' 54 , mice). It is of interest in comparing with the normal data of other mammals, that centrally and somewhat apically situated nuclei are more frequent in golden hamsters. The apical situation of the nuclei has been interpreted to be a sign of hyperactivity (W at zka, '34, mammals, birds; De R obertis, '41, rats).

The cytoplasm is finely granular and rarely loaded with secretory droplets. The droplets have been called also colloid droplets and found generally in the apical zone of the cell. The abundant occurrence of these droplets has been interpreted to be a result of increased thyrotrophic hormone secretion (De $\mathrm{R}$ o b e r t is, '42, guinea pigs), and has been suggested for use as one of the signs for thyrotrophic hormone assay (D voskin, '47, cockerels; '48, rats). The secretory droplets in golden hamsters are spherical, and of varying shades of black by iron hematoxylin stain. In agreement with the data of W e g e li n ('26, man), Sug i y a m a ('39, rats) and $\mathrm{O}$ h i d a ('54, mice), it was found also in golden hamsters that the droplets do not occur frequently in the course of postnatal development. It is of interest in golden hamsters in puberty that colloidal substance appears sometimes in the basal zone of the cell, and the nucleus is displaced towards the apical zone. The substance is homogeneous and stained gray by iron hematoxylin (fig. 11). The follicle cells with such a substance resemble Bensley's cells which have been described to be an intermediate type between the secreting cell and the dying cell as they are capable of releasing colloid droplets (Uh le $n$ h u th, '28, Ambystoma opacum; B a r g m a n n, '39) and at the same time show degeneration of their nuclei. On the other hand, presecretory substance has been observed as vacuoles, which are discharged from the basal pole of the cell into capillaries (B e nsley, '16, opossums). De R obertis ('41) found colloidal substance in the basal zone of the cell in the activated thyroid 
gland. The present finding may suggest a possibility of release into the circulatory system of the substance but at the same time may indicate the stagnation of it as a result of unbalance in function.

No intercellular canalicules ( $\mathrm{H}$ ü $\mathrm{r} \mathrm{th} \mathrm{le}, 1894$, dogs; $\mathrm{M}$ a t s u n a g a, '09, dogs, cats, pigs, rabbits; S p öt te l, '29, sheep ; Ka n o, '52, man), through which the colloid of the follicles is discharged into the circulatory system, were found in golden hamsters.

INTERFOLLICULAR EPITHELIAL CELLS-in a broad sense seem to include various categories (parafollicular cells, macrothyrocytes, argyrophilic cells, nh-cells) of the cells or their groups, which are found between follicles or directly on the follicle walls and further between ordinary follicle cells. Their nuclei have been described to be slightly larger than or as large as those of the follicle cells and their clear cytoplasm has been reported to contain argyrophilic granules by $\mathrm{Ca}$ a l's silver impregnation. Some have added another kind with dark cytoplasm in some rodents ( $\mathrm{S} \mathrm{ugi} \mathrm{y} \mathrm{a} \mathrm{ma,}$ '39, rats; '50, rabbits; '54, guinea pigs). Some investigators have denied their occurrence and regarded them merely as tangential sections of follicles (W i l s o n, '27, man; L u d w i g, '53, rats, guinea pigs, dogs). L u d wig ('54, rats, dogs) stated again that the macrothyrocytes are nothing but the earliest stages of a beginning indirect cell division. B a rgman ('58) found in primates that the cell groups seen in the interfollicular tissue are embodied in sections of solid and hollow buds of large follicles.

The origin and occurrence of the interfollicular epithelial cells have been differently discussed. Some stated that the cells are of embryonic nature (W ölf le r, 1880) or residual cells of the embryonic thyroid gland ( $\mathrm{B} \mathrm{ozz}, 1895)$. Others described that the interfollicular epithelial cells occur through depletion of colloid in follicles (I se n s chmid, '10, infants). B ernard ('27, dogs) found the interfollicular epithelial cells to be the cells of follicles compressed after depletion of colloid. Sanderson-Damberg ('11, man) found that the interfollicular epithelial cell groups develop from budding process in the follicle walls. Feyrter ('53) stated the formation of parafollicular cells by the "endophytische Sprossung mit nachfolgender Abschnürung" in the follicle wall. Florenti n and Grujic ('29 a, b, '30) found in guinea pigs that the epithelial islets found between follicles are not empty follicles but rather cell masses arising through amitotic division from the follicle walls. N o n id e z ('32 a, dogs ; '32 b, '33, mammals) found that the parafol- 
licular cells occur in the follicle walls and migrate from here to form their group in the interstitium. $\mathrm{R}$ a y mond ('32) found this in rabbits. $\mathrm{Ohkubo}$ ('35, dogs) and $\mathrm{Sug}$ i y a ma ('39, rats; ' 50 , rabbits) described the parafollicular cells to be derived by differentiation of the follicle epithelium. Ehre n b rand ('54), in the thyroid glands of guinea pigs following administration of thyrotrophic hormone, and S u gi y a m a ('54), in histogenesis of the same gland of guinea pigs, found that the parafollicular cells develop from follicle cells and new follicles develop in the parafollicular cell groups. Sandritter and Kle in ('54) found two kinds of argyrophilic cell, one the parafollicular cell of $\mathrm{Nonidez}$ and the other the interstitial cell, a special type to be distinguished from the parafollicular cell. Although the ovoid cells of B e n s l e y ('14, opossums) have been described as a special type other than the parafollicular cell by B a r g mann ('39), they may represent a category of the interfollicular epithelial cell.

God win ('37) found peculiar unorganised cellular masses of ultimobranchial origin in the peripheral zone of the thyroid gland of dogs, and called them gray cells. According to him, the gray cells are identical with the parafollicular cells of Nonidez. V a n Dyke ('45) found two kinds of interfollicular epithelial cell in young sheep. According to him, one develops from follicle cells of broken follicles and the other is of ultimobranchial origin. Recently, $\mathrm{Kr}$ oon ('58) found in rats and rabbits that the macrothyrocytes are always seen in thyroid with a proliferative formation of microfollicles, arising both from the follicle walls and mucus secreting branchiogenic tissue in the gland. The neuro-hormonal cell (nhZellen) also may represent a category of the interfollicular epithelial cells. Su nder-P la s s mann ('39 a, b, c) found the nh-Zellen numerously, in or around the follicles of the activated thyroid gland, which migrate from the thymus through the hilus.

The present observation suggested that the parafollicular cells may be of ultimobranchial origin, in agreement with some of the data of Godwin, van Dyke and Kroon. They are clear, polygonal and large. They stain red purple by periodic acid-Schiff's stain and remain unchanged after saliva digestion. No dark parafollicular cells are found in golden hamsters. They appear for the first time on the 3rd day and most of them are found singly or in groups on the follicle walls, without bordering directly the follicle cavities (figs. 9 and 10), and appear most frequently during puberty. 
But some of them border directly the follicle cavity. This led some authors to a conclusion that the parafollicular cells may develop from the follicle cells. It may be supposed that epithelial cells of the ultimobranchial body are more or less extensively scattered in the thyroid parenchyma during embryonic development, and after birth soon develop into the parafollicular cells. No development of the parafollicular cells is found as results of the breakdown of follicles, remnants of the thyroid primordial cells and depletion of colloid. Solid cell masses other than the parafollicular cells are frequently found between follicles, but are merely tangential sections of follicles compressed after depletion of colloid. The problem of differentiation of the parafollicular cells from the follicle epithelium, however, remains still undetermined.

The functional significance of the parafollicular cells has also been the subject of discussion. Some found them to produce new follicles (G o d w i n, '37, dogs ; S u g i y a m a, '54, guinea pigs; K r oo $\mathrm{n}$, '58, rabbits, rats, hamsters). Others considered them to be secreting cells (Bensley, '14, opossums; Takagi, '22, dogs ; O h k u bo, '35, dogs; A rimits u, '37, rats; S ug i y a ma, '50, rabbits; Sugi y a ma, '54, guinea pigs). R a y mond ('32) found them to have some relation with the production of colloid. H ürthle (1894, dogs) found that the interfollicular epithelial cells (Protoplasmareiche Zellen) serve for the growth of the follicles.

From the present observation it may be considered that the parafollicular cells in golden hamsters represent a kind of secreting cell because of their close proximity to capillaries (fig. 9) but are not capable of playing an important role because of their derivation from the ultimobranchial body which degenerates (S a to, '56).

COLLOID-It was found as one of the characteristics of the thyroid gland of golden hamsters that colloid is always poor in content in most of the follicles. It was supposed that the colloid may be resorbed almost as quickly as it is formed. Accumulation of radioiodine has some relation with that of colloid in follicles and is also small in most of the follicles. The colloid appears dark in many follicles of the gland shortly after birth (fig. 4), only in a number of peripheral large follicles at 5 to 10 days (fig. 5), and thereafter the colloid becomes poor in staining and vacuolated with the increase in height of the follicle cells and growth and irregularization of the follicles, and persists in the same condition until puberty (fig. 6). After puberty the colloid becomes again dark in some of the 
peripheral large follicles but faint and vacuolated in others. The colloid is positive to periodic acid-Schiff's stain. This suggests that the colloid exhibits glycoprotein reaction (D e m p s e y, '55).

Marginal vacuolation is always more or less extensively found in the colloid. Already shortly after birth, vacuoles are seen and they increase in number towards puberty. Even after puberty they are still abundantly seen. The vacuoles have been interpreted to be artifacts due to fixation but they have some relation with the increased activity of the thyroid gland. Indeed, the freezing drying method demonstrated no occurrence of vacuoles in the colloid (D e R o bertis, '41). Another study of the colloid of follicles in living mice showed that no vacuoles are present under normal conditions (Williams, '41). The author agrees with these investigators as regards the view of artifacts due to fixation. The number of vacuoles depends upon methods of fixation and also upon the condition of the gland. The higher the follicle cells are, the more irregular the follicles are, and the more faint the colloid is, the more intense is the vacuolation (figs. 6 to 8 ). In studies on the thyroid glands activated by thyrotrophic hormone or by anterior pituitary, a histological picture similar to this finding has been found (A r o n, '30, guinea pigs, rabbits, dogs, cats ; '34, guinea pigs; $\mathrm{Kr}$ og h et al., '33 a, b, guinea pigs).

INTERSTITIAL CONNECTIVE TISSUE-The capsule contains argyrophilic fibers and connective tissue fibers with no elastic fibers. The interlobular connective tissue is more loosely arranged and the formation of lobules is relatively distinct in early life (fig. 5). With advance in age the interlobular connective tissue becomes densely arranged by growth of follicles, and the lobules become indistinct (figs. 7 and 8).

The perifollicular connective tissue contains also argyrophilic fibers with no elastic fibers. The argyrophilic fibers surround follicles directly as a thin layer (fig. 6), called the "Grenzschicht" by B a r gmann ('39) and Bucher ('40), and further enclose circularly the perifollicular capillaries.

Fat cells appear for the first time on the 28th day, and increase with age. The fat cells have been found in other rodents (S u g iy a m a, '39, rats; O hid a, '54, mice). S pag noli et al. ('55) found them in golden hamsters.

BLOOD VESSELS-Shortly after birth the arteries found in the gland are still immature and develop further with the first forma- 
tion of the lamina elastica interna on the 10th day. The veins are accompanied by the arteries. The veins remain less developed even in later life and some of them resemble in structure the sinusaidal capillaries. Most of the veins remain composed only of the delicate intima and adventitia throughout life.

The capillaries of the thyroid gland of golden hamsters form rich plexuses arourd follicles and they ofter bulge into the follicle walls, indenting the basal surfaces. Intraepithelial capillaries in the follicle epithelium have been found in the thyroid gland of Macacus (B u c h e r, '40). Electron microscopy indicates a finding similar to the data of $\mathrm{Bucher}$ (Dempse y et al., '55, rats). But the capillaries are not intraepithelial in a true sense in golden hamsters.

Capillary engorgement is found after birth, becomes mild during the suckling period, and again intense towards puberty, with the increase in height of follicle cells, vacuolation of colloid and irregularization of follicle shape. The capillary engorgement varies from case to case in adults.

In correlating function and histogenesis, it was found that the thyroid gland of golden hamsters shows the following changes at each period of life:

Immediately after birth, the thyroid gland appears microfollicular with a dominant occurrence of dark colloid in many follicles. Follicle cells are rather small. Capillary engorgement is found. During the suckling period the gland changes in appearance with rapid growth of follicles and follicle cells. The colloid increases in amount, staining dark only in peripheral follicles. Capillary engorgement becomes mild. Parafollicular cells begin to appear in this period.

During infancy, the gland changes from the microfollicular type to the macrofollicular type, with irregularization of follicles. The follicle cells become columnar. The colloid becomes further dilute and vacuolated. The capillaries becomes engorged again. The gland during this period indicates an increased activity.

During puberty, the gland shows its more increased activity. and is transitionally macrofollicular with a slight decrease in size of follicles. Follicle cells are columnar with occasional occurrence of secretory droplets in the apical zone and colloidal substance in the basal zone. Parafollicular cells are most numerously found. The colloid is almost absent or very slight. The capillaries are engorged.

During the adult period, the gland indicates a macrofollicular 
trend with signs of mild activity, but varies in appearance from case to case. Follicle cells remain still columnar. The colloid becomes relatively abundant but stains dark only in peripheral follicles.

\section{Summary}

Histogenetical and histological investigations of the thyroid gland of the golden hamster, in combination with quantitative histometrical measurements and radioautography by radioiodine ${ }^{131}$, elucidated the following:

1. Immediately after birth the thyroid gland is composed of small follicles, with a dominant occurrence of dark colloid. Follicle cells are rather generally cubical. Capillary engorgement is found. In the suckling period, the gland rapidly changes in appearance with growth of follicles and follicle cells, and increase of colloid. In infancy the gland appears macrofollicular with dilution and vacuolation of colloid. Follicle cells become columnar. In puberty, the gland indicates a slight reduction in size of follicles (transitionally macrofollicular type), with a more exaggerated appearance of columnar follicle cells, diluted colloid and capillary engorgement. Parafollicular cells occur in abundance. In adults, the gland becomes mild and varies histologically in appearance from individual to individual. The colloid stains dark in the peripheral follicles but feebly in most follicles.

2. The parafollicular cells are probably of ultimobranchial origin and the problem of their differentiation from the follicle epithelium requires re-examination.

3. Radioiodine is poorly accumulated in most follicles but considerably in a number of follicles located peripherally. Its accumulation has a relation with that of colloid in the follicles.

\section{Literafure Gited}

Andersson, O.A.: Zur Kenntñis der Morphologie der Schilddrüse. Arch. Anat. Entw. gesch., 177-221, 1894.

A r im itsu, K.: Zytologische Untersuchungen über die Interfollikularzellen der Schilddrüse der Ratte. I. Normaler Befund. Kaibo Z., $10: 233-245$, 1937, (in Japanese).

Aron, M.: Particularités histologiques de la réaction de la thyroïde aux extraits de lobe antérieur d'hypophyse." C. R. Soc. Biol. (Paris), 103 : 145-147, 1930. : Les tests morphologiques du fonctionnement thyroïdien. 'C. R. Ass. Anat., 
$29: 7-22,1934$.

Aschoff, L.: Vorträge über Pathologie gehalten an den Universitäten und Akademien Japans im Jahre 1924. 1-309, Gustav Fischer, Jena, 1925.

Bargmann, W.: Die Schilddrüsen in v. Möłlendorff's Handb. mikr. Anat., $6: 2$ Tl., 1-136, Julius Springer, Berlin, 1939.

: Thyreoidea und Parathyreoidea. Primatologia, III, Tl. I, 799-809, S. karger, Basel, 1958.

Bensley, R.R.: The thyroid gland of the opossum. Anat. Rec., 8: 431-440, 1914. -: The normal mode of secretion in the thyroid gland. Am. J. Anat., 19: 37-56, 1916.

Berberich, J. und B. Fis cher-W asels: Schilddrüse und innere Sekretion. M. H I R S C H' Handbuch der inneren Sekretion, Bd. 1, 337-431, Curt Kabitzsche, Leipzig, 1932.

Bernard, W.: La thyroïde au cours de la grossesse. Rev. franç. Endocr., 5 : 395$452,1927$.

B o zzi, E.: Untersuchungen über die Schilddrüse. Beitr: path. Anat., 18 : 125-173, 1895.

Bruce, H.M. and E.H. Hindle: The golden hamster, cricetus (Mesocricetus) auratus Waterhouse. Notes on its breeding and growth. Proc. Zool. Soc. Lond., 104 : 361-366, 1934.

Bucher, O.: Intraepitheliale Kapillaren im Follikelepithel der Schilddrüse. Z. Zellforsch., 30 : 432-438, 1940.

Caylor, H.D. and C.F. Schlotthauer: The thyroid glands of swine. Anat. Rec., $34:$ 331-339, 1927.

Cowdry, E.V.: The thyroid in textbook of histology. 149-167, Henry Kimpton, London, 1934.

Dempsey, E.W.: Histology and histochemistry in Werner's The thyroid. 106-119, A Hoeber-Harper Book, N.Y.C., 1955.

De m psey, E.W. and R.R. Peter s o n: Electron microscopic observations on the thyroid glands of normal, hypophysectomized, cold exposed and thiouraciltreated rats. Endocrinology, 56 : 46-58, 1955.

Dvoskin, S.: Intracellular colloid droplets as a basis for thyrotrophic hormone assay in the chick. Endocrinology, 41:220-229, 1947.

: The effects of pituitary and non-pituitary gland factors on the formation of intracellular colloid droplets in the thyroid epithelium of hypophysectomized rats. Endocrinology, $43: 52-70,1948$.

van Dyke, J.H:: Behaviour of ultimobranchial tissue in the post-natal thyroid gland: epithelial cysts, their relation to thyroid parenchyma and to "new growths" in the thyroid gland of young sheep. Am. J. Anat., 76: 201-251, 1945.

Ehrenbrand, F.: Unterșuchungen über Genese und Funktion der parafollikulären Zellen der Schilddrüse. Z. mikr.-anat. Forsch., $60: 337-354,1954$.

F e y rter, F.: Über die peripheren endokrinen (parakrinen) Drüsen des Menschen. 2. erweiterte Aufl., 1-231, Wilhelm Mandrich, Wien, 1953.

Florentin, P.: Persistance d'une structure embryonnaire dans le corps thyroïde du hérisson adulte. C. R. Soc. Biol. (Paris), 105: 591-592, 1930.

Florentin, P. et M. Grujic: Nouvelles observations sur le mécanisme de la

- régénération des follicules thyroïdiens chez le cobaye. C. R. Soc. Biol. (Paris), 100 : 1139-1141, 1929a. 
: Régénération expérimentale du parenchyme thyroïdien. C. R. Soc. Biol. (Paris), 102: 849-851, $1929 \mathrm{~b}$.

: Recherches caryométriques sur la gland thyroïde du cobaye. C. R. Soc. Biol. (Paris), 105 : 938-939, 1930.

Ge ue r, C.: Morphologie und Histologie der Pferde-schilddrüse (unter Berücksichtigung des Einflusses von Alter, Geschlecht, Rasse, Jahreszeit und besonders vom Jodgehalt). Z. Anat., 95 : 473-496, 1931.

Godwin, M. Cr.: Complex IV in the dog with special emphasis on the relation of the ultimobranchial body to interfollicular cells in the postnatal thyroid gland. Am. J. Anat., 60 : 299-339, 1937.

Goormaghtigh, N. and Fr. Thomas: The functional reactions of the human thyroid. A contribution to its histophysiology. Am. J. Path., 10:713-730, 1934.

$\mathrm{H}$ a m mer, E. und H. Loeschcke: Der feinere Bau der Schilddrüse und die sich aus ihm ergebenden Vorstellungen über das Wesen der Proliferationsknospen. Zbl. Path., 60 : Erg.-H., 204-215, 1934.

Heidenhain, M.: Über verschiedene Typen im Bau der Schilddrüse. Anat. Anz., Erg.-Bd., 54 : 141-151, 1921.

Hellwig, C. A.: Die Lebenskurve der nordamerikanischen Schilddrüse. Endocrinology, 12: 323-336, 1933.

Hermann, R.G.: Prinzipielles zu Bau und Tätigkeit der Schilddrüse. Z. mikr.anat. Forsch., 33 : 534-546, 1933.

Hü $\mathrm{rth}$ le, K.: Beiträge zur Kenntnis des Sekretionsvorganges in der Schilddrüse. Pflügers Arch., $56: 1,1894$, (cited by Bargmann, '39).

Is en s ch mid, R. : Zur Kenntnis der menschlichen Schilddrüse im Kindesalter mit besonderer Berücksichtigung der Herkunft aus verschiedenen Gegenden im Hinblick auf die endemische Struma. Frankf. Z. Path., 5: 205-252, 1910.

Jackson, C.M.: Effects of inanition upon the structure of the thyroid and parathyroid glands of the albino rat. Am. J. Anat., 19: 305-352, 1916.

Kano, K.: Zytologische Untersuchungen über die menschliche Schilddrüse mit besonderer Berücksichtigung der Ausschwemmung des intrafollikulären Kolloides durch die interzellulären Kanälchen. Arch. hist. jap., 4: 245-274, 1952, (in Japanese).

Klose, H.: Die pathologisch-anatomische Grundlage der Basedow'schen Krankheit. Nach vergleichend pathologischen und klinischen Studien. Bruns Beitr. klin. Chir., 102: 1-12, 1916.

Kolmer, W.: Endokrine Drüsen. R. JAF F E's Anatomie und Pathologie der Spontanerkrankungen der kleinen Laboratoriumstiere. Julius Springer, Berlin, 1931.

$\mathrm{Kr} \circ \mathrm{gh}$, M. et $\mathrm{H}$. Okkels: Quelques résultats récents de l'histophysiologie thyroïdienne. Bull. histol. appl., 10:105-112, 1933 a. : Sur l'histophysiologie du corps thyroïde. Stades initiaux de la sécrétion thyroïdienne. C. R. Soc. Biol. (Paris), 112: 1694-1696, 1933 b.

Kroon, D. B.: The macrothyrocyte as a functional stage of the thyroid cell. Acta anat., 33 : 76-104, 1938.

$\mathrm{Ku}$ le $\mathrm{n} \mathrm{a} \mathrm{m} \mathrm{p} \mathrm{f,} \mathrm{H.:} \mathrm{Acini} \mathrm{und} \mathrm{Lymphsinus} \mathrm{in} \mathrm{der} \mathrm{Schilddrüse} \mathrm{des} \mathrm{Neugeborenen.}$ Z. Anat. Entw. gesch., 115: 82-87, 1950.

Ludwig, K.S.: Beiträge zur Schilddrüsenstruktur: II. Gibt es "inter-oder parafollikuläres" Epithel in der Schilddrüse? Acta anat., 19: 28-50, 1953. 
: Beiträge zur Schilddrüsenstruktur: III. Zur Frage der Makrothyreocyten in der Schilddrüse nebst histophysiologischen Bemerkungen. Acta anat., 20 : $1-36,1954$.

Matsunaga: Die parenchymatösen Lymphbahnen der Thyreoidea und ihre Sekretion. Arch. Anat., Anat. Abt., 339-348, 1909.

Montez de Oca: Das histologische Bild der japanischen Schilddrüse als Norm. Beitr. path. Anat., 85 : 333-348, 1930.

Nonidez, J.F.: The origin of the "parafollicular" cell, a second epithelial component of the thyroid gland of the dog. Am. J. Anat., 49: 479-505, $1932 \mathrm{a}$. : Further observations on the parafollicular cells of the mammalian thyroid. Anat. Rec., 53 : 339-347, 1932 b.

: The "parenchymatous" cells of BABER, the "protoplasmareichen Zellen" of HÜRTHLE, and the "parafollicular" cells of mammalian thyroid. Anat. Rec., 56 : 131-141, 1933.

$\mathrm{O}$ hida, S.: Histological studies of the thyroid gland of the mouse after castration. Okajimas Fol. anat. jap., 26 : 347-371, 1954.

Ohkubo, K.: On the studies of parafollicular cells (Nonidez) in thyroid glands of dogs. Jap. J. Med. Sci., I. Anatomy, 5: 47-60, 1935.

R a y mond, N.: The occurrence of parafollicular cells in the thyroid of the rabbit. Anat. Rec., 53 : 355-365, 1932.

DeRobertis, E.: The intracellular colloid of the normal and activated thyroid gland of the rat studied by the freezing-drying method. Am. J. Anat., 68: 317-337, 1941.

- : Intracellular colloid in the initial stages of thyroid activation. Anat. Rec., 84 : 125-135, 1942, (cited by Dvoskin, '47).

S a nder s o n-D a m ber g: Die Schilddrüse vom 15.-25. Lebensjahr. Frankf. Z. Path., $5: 312-334,1911$.

Sandritter, W. und K.H. Kle in: Über argyrophile Zellen in der Schilddrüse. Frankf. Z. Path., 65 : 204-218, 1954.

Sato, T.: On the ultimobranchial body of the golden hamster in postnatal life. Kaibo Z., 31 : Supp., 4, Abstract, 1956, (in Japanese).

Sobotta, J.: Anatomie der Schilddrüse (Glandula thyreoidea). Handbuch der Anatomie des Menschen. 6 : Abt. 3, 155̣-197, Guștav Fischer, Jena, 1915.

$\mathrm{Spagnoli}, \mathrm{H} . \mathrm{H}$. and H.A. Charipper: The effects of aging of the histology and cytology of the pituitary gland of the golden hamster (cricetus auratus), with brief reference to simultaneous changes in the thyroid and testis. Anat. Rec., 121 : 117-139, 1955.

Spöttel, W.: Die Abhängigkeit der Schilddrüsenausbildung von Rasse, Alter, Geschlecht und Jahreszeit bei verschiedenen Schafrassen. Z. Anat., 89: 607-671, 1929.

St ef ko, W.H.: Beiträge zur Kenntnis Konstitutions-anatomischer Besonderheiten der Organe (vom Standpunkte der postnatalen Entwicklung). Z. Konst.lehre., 18 : 287-310, 1934.

$\mathrm{Sug}$ i y a ma, S.: The morphogenetic and histogenetic studies of the thyroid gland of the albino rat. Nagoya Igakkai Z., 50: 1171-1246, 1939; (in Japanese).

: On the postnatal histogenesis of the thyroid gland of the rabbit. I. On the glandular cells (follicle cell and parafollicular cell). Okajimas Fol. anat. jap., 23 : 57-65, 1950.

- : Studies of the histogenesis of the thyroid gland of the guinea pig. I. 
The thyroid cells (follicle. cells and parafollicular cells). Anat. Rec., 120 : 363$378,1954$.

Sugiy a ma, S. and T. Sato: Studies of the histogenesis of the thyroid gland of the guinea pig. II. Quantitative measurements of the follicles and correlation with function. Anat. Rec., $120: 379-394,1954$.

Sugi y a ma, S., K. Takeuchi, Y. A ida and A. Taki: The follicles in the thyroid gland of the newborn child. Okajimas Fol. anat. jap., 30 : 411-420, 1958.

$\mathrm{Sug}$ i y a ma, S. and T. Yagizawa: On the postnatal histogenesis of the thyroid gland of the rabbit. 3. On the thyroid function researched from the histogenetic point of view. Okajimas Fol. anat. jap., $23: 67-80,1950$.

Sunder-PIassma n n, P.: Nervensystem und Schilddrüse. Dtsch. Z. Chir., 252 : $1-18,1939$ a.

: Über neuro-hormonale Zellen des Vagussystems in der Schilddrüse. Dtsch. Z. Chir., 252 : 210-223, 1939 b.

- Zum Basedow-Thymus-Problem. Dtsch. Z. Chir., 252: 257-268, $1939 \mathrm{c}$.

Takagi, K.: A cytological study on the dog's thyroid gland. Okajimas Fol. anat. jap., 1 : 69-100, 1922.

Uhlenhuth, E.: 1928, (cited by Bargmann, '39).

W at zka, M.: Physiologische Veränderungen der Schilddrüse. Z. mikr.-anat. Forsch., $36: 67-86,1934$.

W e ge l i n, C.: Schilddrüse. in Henke-Lubarsch's Handb. spez. path. Anat. u. Hist., 8 : 1-47, Julius Springer, Berlin, 1926.

Willi a ms, R.G.: Studies of vacuoles in the colloid of thyroid follicles in living mice. Anat. Rec., 79 : 263-270, 1941.

Wilson, G.E.: The thyroid follicle in man: its normal and pathological con. figuration. Anat. Rec., $37: 31-60,1927$.

W ölf ler, A.: Über die Entwicklung und den Bau der Schilddrüse mit Rücksicht auf die Entwicklung der Kröpfe. Berlin, 1880, (cited by Wegelin, '26).

Yagizawa, T.: The follicular pattern in the thyroid gland of maturing and mature mammals. Okajimas Fol. anat. jap., 29 : 93-116, 1956.

$\mathrm{Zalesky,} \mathrm{M.:} \mathrm{A} \mathrm{study} \mathrm{of} \mathrm{the} \mathrm{seasonal} \mathrm{changes} \mathrm{in} \mathrm{the} \mathrm{thyroid} \mathrm{gland} \mathrm{of} \mathrm{the}$ thirteen-lined ground-squirrel (Citellus tridecemlineatus), with particular reference to its sexual cycle. Anat. Rec., 62: 109-133, 1935.

Zechel, G.: Follicular destruction in the normal thyroid of the dog. Surg. Gynec. Obstetr., 52 : 228-232, 1931 a.

: Experimental regeneration of the thyroid gland. Surg. Gynec. Obstetr., $53: 12-15,1931$ b.

: Observations on the follicular cycle and on the presence of the "macrothyrocyte" in the human thyroid. Anat. Rec., $56: 119-130,1933$.

\section{Explanation of Plate Figures}

4. 12 hours after birth. Female. The gland is microfollicular. Many of the follicles contain dark colloid. Primitive follicles (arrows) are seen as buds in the follicle wall, and some of them form cords. Follicle cells are low cubical. Kolster. Iron hematoxylin. $\times 280$.

5. 3 days after birth. Male. The gland remains microfollicular. Many of the 
follicles contain feebly stained colloid. Follicle cells are cubical. Interlobular connective tissue is loosely arranged. Kolster. Iron hematoxylin. $\times 135$.

6. 50 days after birth. Female. The gland is transitionally macrofollicular. Many of the follicles contained feebly stained, vacuolated colloid. Some of the follicles are found connecting with other follicles. Follicle cells are columnar. Argyrophilic fibers form perifollicular layers. Some of the capillaries bulge into the follicle epithelium, indenting their basal surfaces. Helly. Bielschowsky's silver impregnation and Hansen's hematoxylin. $\times 135$.

7. 100 days after birth. Male. The gland is macrofollicular. Many of the follicles contain feebly stained, vacuolated colloid. Follicle cells are columnar. Kolster. Iron hematoxylin. $\times 135$.

8. 200 days after birth. Female. The gland is macrofollicular. Many of the follicles are irregular-shaped and contain feebly stained, vacuolated colloid. Follicle cells are columnar. Capillaries are engorged. Kolster. Iron hematoxylin. $\times 135$.

9. 55 days after birth. Male. Parafollicular cells (arrows) are located closely upon the follicle walls, singly or in groups, and at the same time directly upon the capillaries. Their nuclei and cell bodies are larger than those of the follicle cells. Kolster. Iron hematoxylin. $\times 520$.

10. 5 days after birth. Female. Parafollicular cells (arrows) are abundantly distributed in follicles found near the cysts of ultimobranchial origin (Ult). Follicle cells are cubical. Many of the follicles contain darkly stained but vacuolated colloid. Kolster. Iron hematoxylin. $\times 280$.

11. 75 days after birth. Male. Three follicle cells (arrow) contain dilute colloidal substance in their basal zone. Their nuclei are pyknotic and displaced towards the apical portion. Ordinary follicle cells are columnar and swollen. Colloid in the follicle cavity (Cav) is much vacuolated (Va). Kolster. Iron hematoxylin. $\times 800$.

12. 120 days after birth. Female. Part of wax plate reconstruction models of follicles (A, B, C, D, E, F), that connect with each other without open com. munication of their cavities. $\times 500$.

13. 31 days after birth. Male. Radioautograph. Accumulation of radioiodine is seen in a number of peripheral follicles. Bouin. Hematoxylin and eosin. $\times 70$.

14. 122 days after birth. Male. Radioautograph. Accumulation of radioiodine seen in a number of peripheral follicles, but not found in cysts of ultimobranchial origin (Ult). Bouin. Hematoxylin and eosin. $\times 70$. 
Plate I
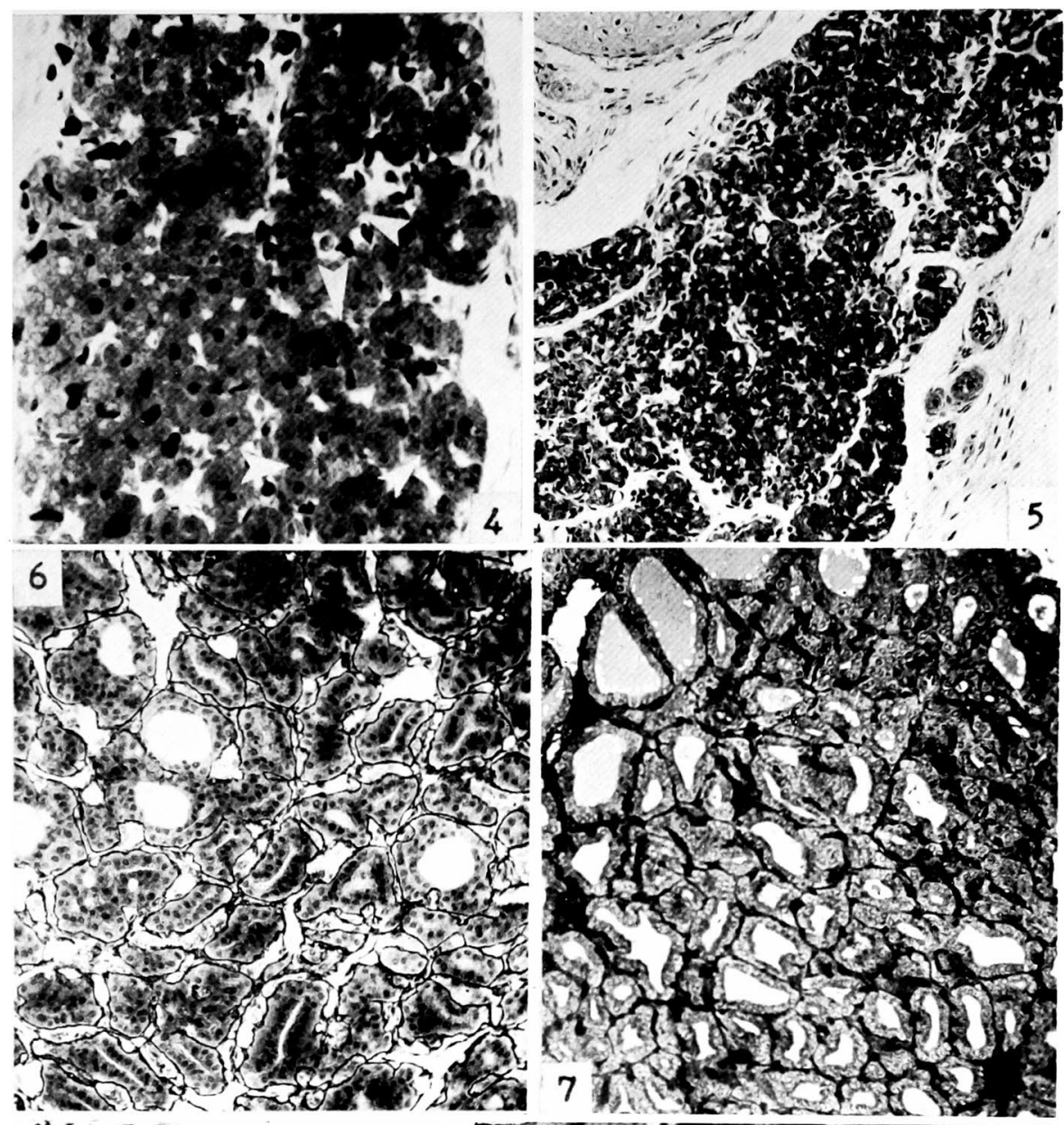

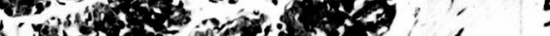
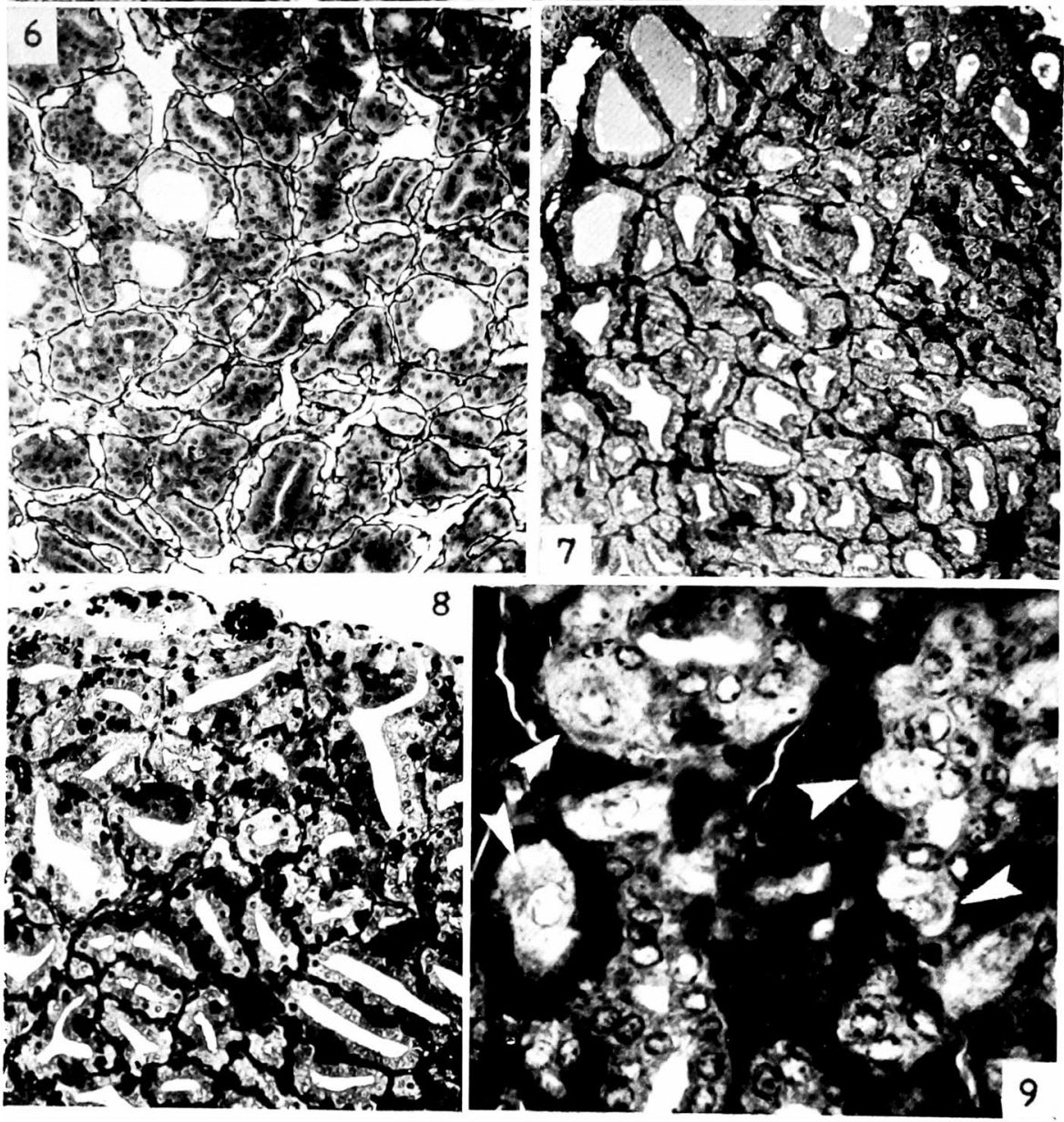

T. Sato 
Plate II
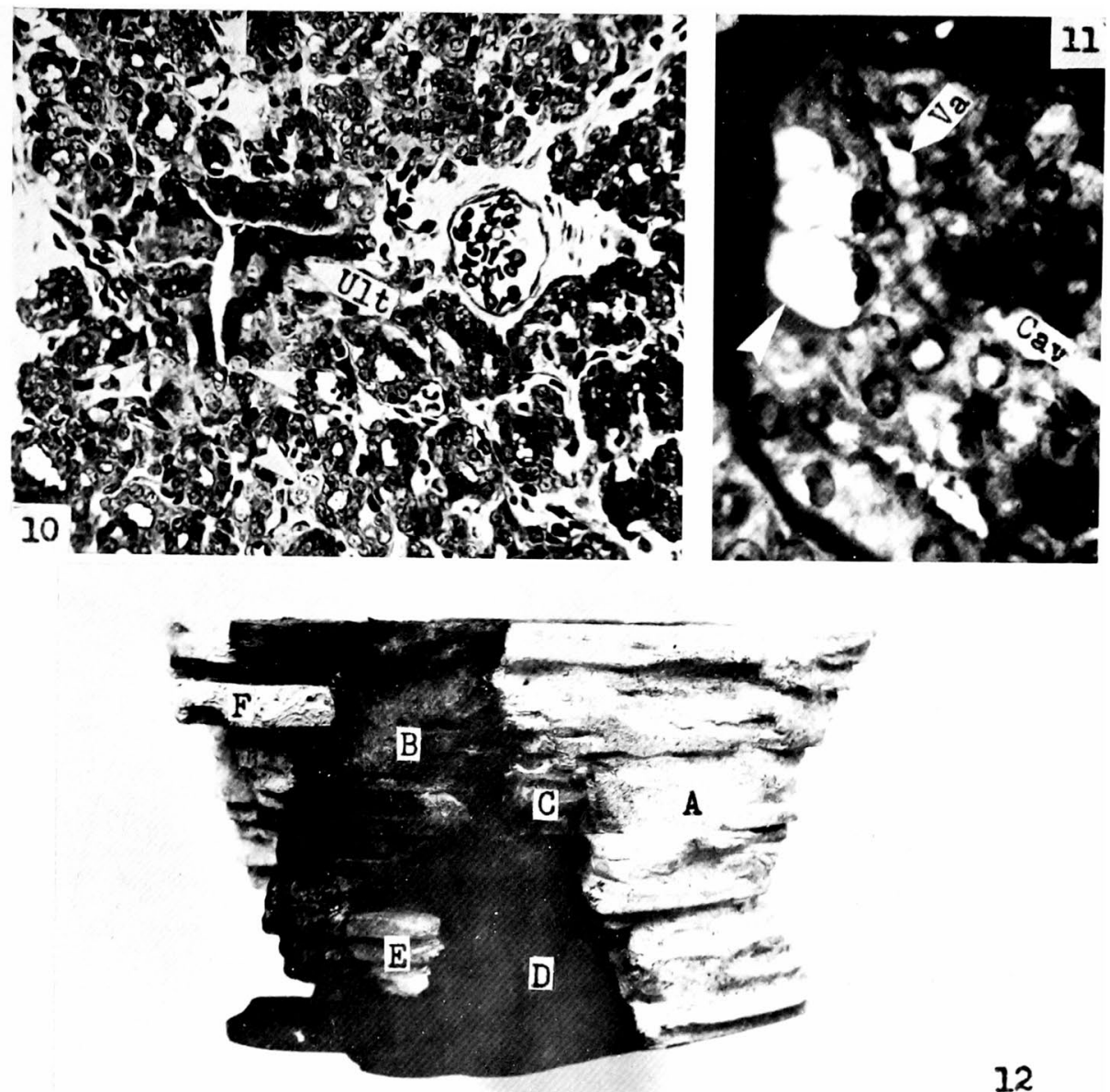

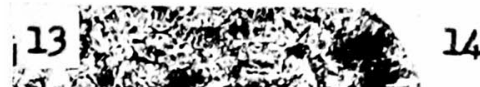

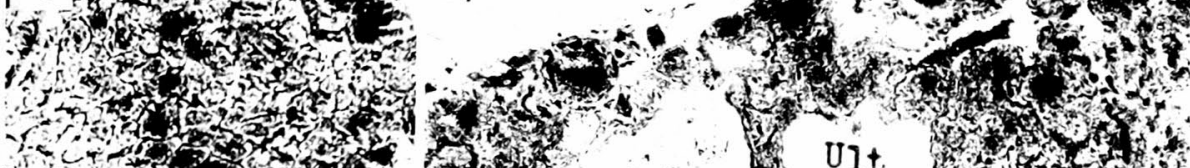

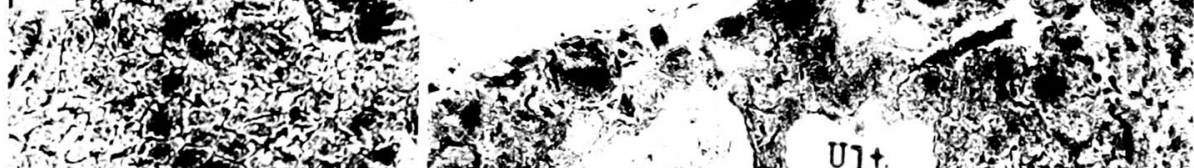

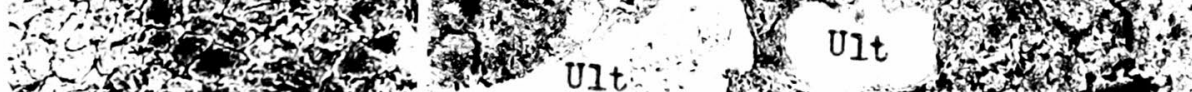

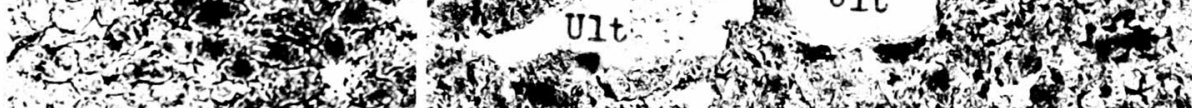
3.

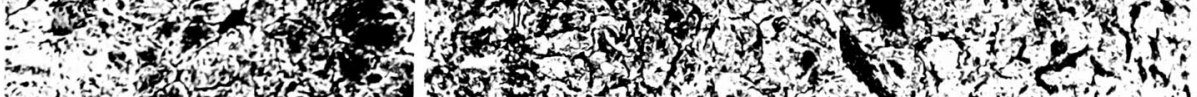

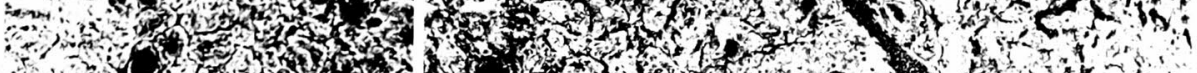

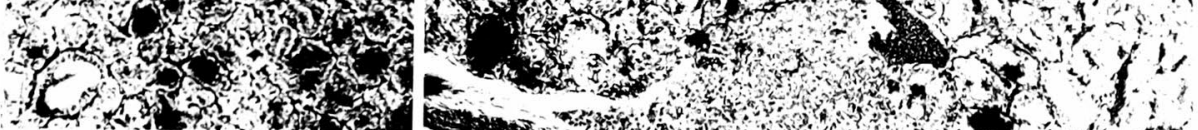

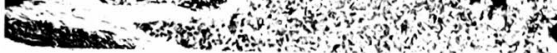

T. Sato 